\title{
China, Russia, and the Foreign Policy of the SCO
}

\author{
Flemming Splidsboel Hansen *
}

Having celebrated its tenth anniversary in 2011, the Shanghai Cooperation Organization (SCO) can be said to have risen rapidly to a position of prominence in the world of regional organizations. Part of the reason for this is found in the successful political marketing of the organization, a process which has seen the member states openly promote their ambition to develop a strong Asian bloc based on both wider and deeper cooperation. As was made clear by the 2001 Declaration on the Establishment of the SCO, this ambition includes the development within the organization of a culture of "close cooperation on the most important international and regional problems." 1

A high level of agreement on aims and modalities among the members of the group - a precondition for close foreign policy cooperation - will indicate that they may more readily form a united policy front and thus find it easier to have an impact on their surrounding environment. Conversely, a low level of agreement will indicate that they will find it relatively difficult to stand together shoulder-to-shoulder and to achieve the ambitions outlined in the Declaration.

\section{Assessing SCO Cohesion}

What follows is an assessment of the actual level of foreign policy cohesion within the membership circle. This includes most importantly the six current full members: China, Russia, Kazakhstan, Kyrgyzstan, Tajikistan (the founders in 1996 of the Shanghai Five, the predecessor of the $\mathrm{SCO}$ ), and Uzbekistan, which joined the $\mathrm{SCO}$ at the founding meeting in 2001. ${ }^{2}$ To this group I add the original four observer states-Mongolia (which joined in 2004) as well as India, Iran, and Pakistan (all of which joined in 2005) - as these are the most likely candidates for future full membership. ${ }^{3}$

I measure the level of foreign policy cohesion within the SCO by analyzing the voting records of the ten member and observer states in the United Nations General Assembly. The voting record of each state is seen as a proxy for its foreign policy behavior. These types of studies date back to the 1950s, making this a well-tried and oft-used methodology which can help provide us with quantifiable information as we speculate

* Flemming Splidsboel Hansen, Ph.D., is Research Director at the Danish Defense College in Copenhagen. The author gratefully acknowledges the financial support of the Carlsberg Foundation.

1 Shanghai Coooperation Organization, "Deklaratsiya o sozdanii shankhaiskoi organizatsii sotrudnichestvo," 15 June 2001; available at http://www.sectsco.org/RU/show.asp?id=83.

2 For an introduction to the Shanghai Five and the SCO, see Flemming Splidsboel Hansen, "The Shanghai Co-operation Organisation," Asian Affairs 39:2 (2008): 217-32.

3 Afghanistan was granted observer status at the June 2012 SCO summit in Beijing; this decision was made after the completion of the present article and the voting record of Afghanistan was therefore not included in the data set. 
about the possible changes in the foreign policy of a single state or in the relationship between two or more states. ${ }^{4}$

\section{The Toolbox}

The data set used in this analysis is the voting records of the SCO member and observer states, all of which are freely available on the United Nations website. ${ }^{5}$ In order to present a fuller picture of the development of foreign policy in these respective states I expand the temporal basis by using data from General Assembly Sessions 47 through 65, beginning in September 1992 and ending in July 2011. This means that I include data reaching back before the establishment of the SCO and even the Shanghai Five. Within this time span, I extracted data from every second session, giving me data from a total of ten different sessions.

The data collection methodology was based on three basic principles. ${ }^{6}$ First, I only used votes on resolutions passed (thereby excluding resolutions that were rejected as well as parts of resolutions). Second, from this data set I included only roll call (recorded) votes. These two principles combined result in a pool of more than 700 recorded votes. These votes form the basis for the following analysis. The third and final principle is to treat absenteeism as abstention. On each of the more than 700 votes, the SCO member or observer states had the choice of voting "Yes" or "No," or abstaining. A fourth option, however, is to simply choose to be absent - that is, not take part in the voting altogether.

Faced with the challenge of absenteeism, some researchers simply throw out all cases with less than full participation by all the objects of analysis. ${ }^{7}$ However, as Uzbekistan, Kyrgyzstan, and Tajikistan all had high levels of absenteeism in several sessions, this clearly would not work in this study. Such an approach would leave a much-reduced pool of votes, and these remaining votes would, moreover, be unevenly scattered across various sessions, making the final result a highly skewed set of findings without much validity.

What I do instead is to treat absenteeism as abstention, thus assigning a "middle" position to the state. The basic assumption behind this principle is that the country is regarded as not knowing how to vote - "it is 'in-between' a pro and a contra vote." ${ }^{8}$ However, if a member state was absent for more than one-third of all recorded votes during a

4 Steven Holloway, "Forty Years of United Nations General Assembly Voting," Canadian Journal of Political Science 23:2 (1990): 279-96; and Erik Voeten, "Clashes in the Assembly," International Organization 54:2 (2000): 185-215.

5 At http://unbisnet.un.org.

6 See Paul Luif, "EU Cohesion in the UN General Assembly," Institute for Strategic Studies Occasional Papers 49 (2003): 22-23; and Elisabeth Johansson-Nogués, "The Voting Practice of the Fifteen in the UN General Assembly: Convergence and Divergence," Observatori de Politica Exterior Europea Working Paper 54 (2004).

7 Johansson-Nogués, "The Voting Practice."

8 Luif, "EU Cohesion." 


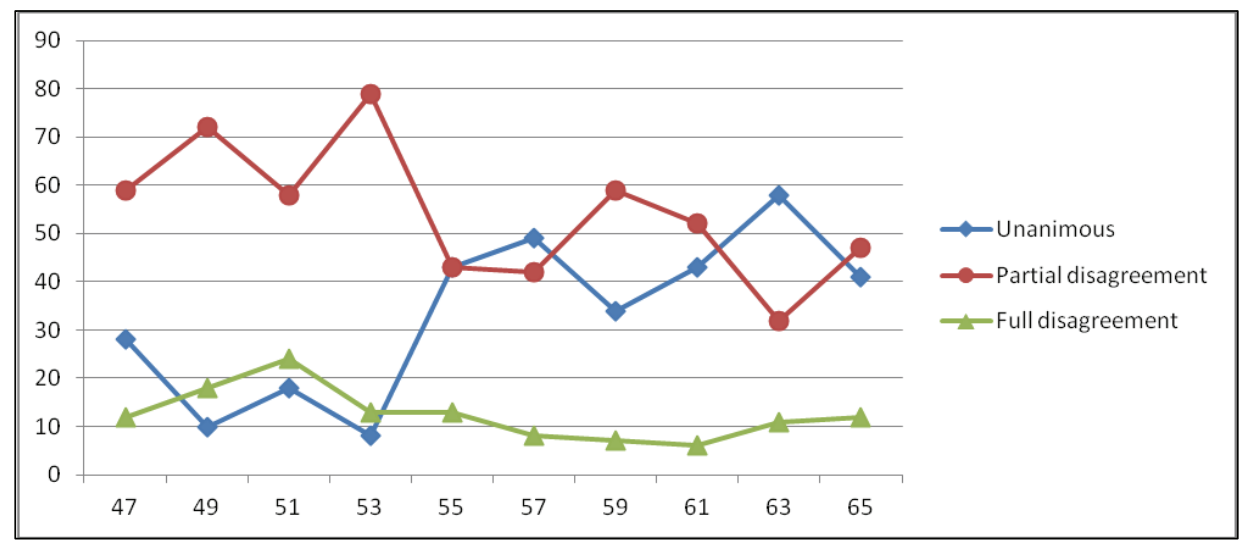

Figure 1: The Overall Pattern of Cohesion.

single session, data for this particular state were not included in the data set for the year in question.

This rule applies to three different member states and to five different sessions. Tajikistan has shown remarkably poor voting discipline in the General Assembly; voting data for the country are excluded from Sessions 47 and 51-57. Data for Uzbekistan are excluded from Sessions 47 and 55-57, and for Kyrgyzstan from Sessions 47 and 57.

\section{The Overall Pattern}

I began by looking at the overall voting pattern of the $\mathrm{SCO}$ as a whole. This was done by classifying the data into three categories according to the distance between the states on the spectrum "Yes-Abstention-No." The first category is that of unanimous votes on which there was full agreement. The second category contains votes that featured a twoway split (or partial disagreement) where at least one state abstained while the others voted either "Yes" or "No" (but not both). The third group consists of votes that were split three ways (or full disagreement), where at least one state voted "Yes" while at least one other state voted "No." Figure 1 shows the result $(\mathrm{X}$ axis $=$ session; $\mathrm{Y}$ axis $=$ percentage of total number of recorded votes).

The chart reflects, first, that the share of unanimous votes saw dramatic variations in the years from 1992 to 2011, and that the picture is indeed a rather complex one. This is partly as a result of absenteeism, which unfortunately colors the findings. When viewed as a whole, this time period witnessed a 13 percentage point increase in the share of unanimous votes (from 28 percent in Session 47 to 41 percent in the Session 65). There is little doubt that this figure would have been higher had Kyrgyzstan, Tajikistan, and Uzbekistan not all been excluded from the data set for Session 47 as a result of extreme absenteeism. All moderate outliers at the time, their votes undoubtedly would have re-

9 Johansson-Nogués, "The Voting Practice," 4. 
duced the level of unanimity during this first session, and thus provided a bigger overall increase in the share of unanimous votes across the ten sessions.

When examining only Sessions 57-65 more closely - that is, the years 2002-2011we find that the share of unanimous votes actually decreased by 8 percentage points. As will be demonstrated below, Uzbekistan developed a foreign policy that made it a very strong outlier in the group in the late 1990s. If Uzbekistan's votes had been included in the data set for Session 57, this one country's actions alone would have caused the share of unanimous votes to fall to 14 percent (from 49 percent) and the share of two-way splits to increase to 78 percent (instead of 42 percent). The figures for Session 55 would have been 12 and 75 percent, respectively, instead of 43 percent and 43 percent. It should, however, be made clear that these figures are surrounded by a very high degree of uncertainty, as a large percentage of the Uzbek votes currently included were absentee votes (which are treated here as abstentions).

However, given the earlier record of Uzbek voting, there is good reason to speculate that the country would in fact have continued (although possibly with some moderation) the strong independence that so characterized its foreign policy in the years preceding its decision to enter the SCO in 2001 (see Table 1). Not only would this have delayed the increase in the share of unanimous votes, it would also have "flattened" it, thereby giving the SCO more credit as a homogenizing agent. Thus, we should expect that if the Uzbek votes were included in the data set for Session 57, the overall picture would show that the SCO member and observer states had actually increased — not decreased — their number of unanimous votes in the years 2002-2011.

These speculations aside, Sessions 59-65, which include data from all ten states, show an average share of unanimous votes of 44 percent (within a range of 34 to 58 percent). By comparison, the EU has consistently recorded a share of unanimous votes of well over 75 percent - and this with a much larger group of member states. ${ }^{10}$ Little in the post-2001 pattern seems to suggest that the SCO will be able to reach a similar level of unanimity in its second decade, whether through socialization or instrumental votecasting, where typically the less powerful states follow the lead of the more powerful ones in order to gain benefits or avoid punishments.

What these data also indicate are different levels of disagreement. The share of twoway splits has varied almost inversely with the share of unanimous votes, and has been affected by the problem of absenteeism in a similar way. This type of disagreement (as opposed to full disagreement) indicates that a given state has a policy preference that is only slightly at odds with that of the majority on a given issue. The voting record also suggests, however, that less powerful states may be reluctant to oppose more powerful ones directly in three-way splits. It is interesting to note how Tajikistan, Kyrgyzstan, and Mongolia - all relatively weak in terms of their capabilities - have a pattern in their ration of votes in two-way and three-way splits that seems disproportionately tilted towards the former. Highly dependent on their partners in the SCO, these states may have drawn the conclusion that their dissent was best expressed in moderation.

10 Ibid., 6; and Luif, "EU Cohesion," 28. 
Table 1: The Distance of Member and Observer States from the SCO Mean.

\begin{tabular}{l|cccccccccc}
\hline & $\mathbf{4 7}$ & $\mathbf{4 9}$ & $\mathbf{5 1}$ & $\mathbf{5 3}$ & $\mathbf{5 5}$ & $\mathbf{5 7}$ & $\mathbf{5 9}$ & $\mathbf{6 1}$ & $\mathbf{6 3}$ & $\mathbf{6 5}$ \\
\hline CHI & 5 & 5 & 3 & 7 & 3 & 3 & 3 & 2 & 5 & 3 \\
IND & 4 & 11 & 11 & 13 & 6 & 8 & 8 & 8 & 9 & 8 \\
IRN & 3 & 11 & 9 & 9 & 3 & 5 & 5 & 5 & 7 & 6 \\
KAZ & 17 & 7 & 13 & 7 & 11 & 12 & 3 & 5 & 4 & 3 \\
KYR & $\mathrm{n} / \mathrm{a}$ & 11 & 15 & 10 & 7 & $\mathrm{n} / \mathrm{a}$ & 5 & 4 & 2 & 11 \\
MON & 6 & 2 & 6 & 7 & 5 & 11 & 6 & 9 & 8 & 4 \\
PAK & 3 & 2 & 3 & 7 & 4 & 4 & 4 & 5 & 5 & 5 \\
RUS & 26 & 20 & 20 & 13 & 8 & 12 & 8 & 6 & 9 & 10 \\
TAJ & $\mathrm{n} / \mathrm{a}$ & 15 & $\mathrm{n} / \mathrm{a}$ & $\mathrm{n} / \mathrm{a}$ & $\mathrm{n} / \mathrm{a}$ & $\mathrm{n} / \mathrm{a}$ & 8 & 7 & 3 & 7 \\
UZB & $\mathrm{n} / \mathrm{a}$ & 9 & 26 & 28 & $\mathrm{n} / \mathrm{a}$ & $\mathrm{n} / \mathrm{a}$ & 16 & 9 & 3 & 5 \\
\hline
\end{tabular}

The level of full disagreement among the member and observer states has been relatively low. While reaching highs of 18 and 24 percent in Sessions 49 and 51, respectively, in general it has remained relatively close to the 10 percent mark. This general pattern means that the member and observer states have held directly opposing views on approximately only every tenth vote. These three-way splits have mainly been produced by India and Russia, both of which held minority positions in three-way splits far more often than the other states. While India did so quite consistently across the period in question, Russia mainly voted in the minority in three-way splits during the 1990s. Following a policy change dictated by Russian President Vladimir Putin early in the 2000s, it moved closer to the mean, and since then has caused fewer three-way splits. The full disagreements have primarily been provoked by votes on security issues (especially nuclear proliferation and disarmament) and, earlier, on human rights, where Russia often voted in complete isolation from the other states in the group to condemn alleged human rights violators, including even Iran.

\section{The SCO Mean}

The voting patterns presented in Figure 1 only inform us about the SCO as a whole; they do not tell us anything about the behavior of individual states. We may find information on this instead by looking at the SCO mean or "average" voting record and calculating each state's distance from this figure. I arrived at this value by identifying all absolute majorities among the SCO member and observer states included in the data set for the various sessions and then assigning values to each state based on their distance from this majority. The standard absolute majority will be 50 percent plus one- that is, six states. However, since a number of states have been excluded from a number of sessions be- 
cause of absenteeism, the absolute majority will vary; in Sessions 47 and 57 it is only four, while in Sessions $51-55$ it is five.

If a state forms part of an absolute majority, it receives a score of 0 ; if it votes against the absolute majority in a two-way split (partial disagreement), it receives a score of $1 / 2$; and if it votes against the absolute majority in a three-way split (full disagreement), it receives a score of 1 . The combined total is then presented as a share (in percentage terms) of the total number of recorded votes in a given session. The results are presented in Table $1(0=$ minimum distance; $100=$ maximum distance $)$.

The figures show an overall convergence on the mean, regardless of whether this is measured as the maximum outlier position (from 26 percent in Session 47 to 11 percent in Session 65) or as an average distance (from 9.1 percent in Session 47 to 6.2 per cent in Session 65). When viewed in isolation, Sessions 59-65 point in the same direction, although the development is less clear. There was a slight divergence in the years 20092011, but no firm conclusions can be drawn on this weak temporal basis.

We see that China clearly is closer to the mean voting behavior than any other SCO member or observer state. In seven of the ten sessions the country had the shortest distance to the mean, and with an average distance score of only 3.9, its positions epitomize the "SCO foreign policy line." It is followed by Pakistan and Iran (with average distance scores of 4.2 and 6.3 , respectively).

A leading member of what Eric Voeten has called "the counterhegemonic group" in world politics, China has led the overall coalescence of opinion within the SCO in this same anti-Western direction. ${ }^{11}$ This policy rejects the alleged universality of the democratic and human rights agenda of the West and instead insists that traditional state sovereignty be respected and the principle of non-interference in the domestic affairs of other nations be observed. ${ }^{12}$ Featuring a maximum distance score of 7 during the period examined here (and in the twenty-first century scoring no higher than 5), a picture emerges of a country that has largely stayed where it decided to stand, observing from this position how the other member and observer states in general have moved still closer toward it.

This analysis also reveals that Russia has been a strong outlier. In four of the ten sessions the country had the greatest distance from the mean voting position. With an average distance score in the ten sessions of a full 13.2, Russia trails only the quite unpredictable Uzbekistan. As seen in Table 1, the voting record of the latter has been very dramatic - going from high levels of dissent to high levels of conformity - giving it an average distance score of 13.7 over seven sessions. A relatively distant third, India has an average distance score of 8.6. When looking at Sessions 59-65 in isolation, we find that with average distance scores of 8.3 these three same states tie each other for the position as the leading outlier from the mean SCO position.

As seen in Table 1, Russia has only gradually gravitated toward a more consensual position. It is important to add that this move toward the mean was caused by the change

11 Voeten, "Clashes in the Assembly," 213.

12 Alastair Iain Johnston, “Is China a Status Quo Power?," International Security 27:4 (2003): 556. 
in Russian policy mentioned above, rather than by a process through which the other states gradually and increasingly voted with Russia. ${ }^{13}$ Following this re-definition by Putin of Russia's view on what is right and wrong in the world, the country has kept the frequency of its dissent from the SCO mean in the range of 8-12 percent.

The changes in policy in Russia and Uzbekistan, the two early outliers, may of course be rolled back at some future point, but it does seem that both countries have defined more stable policy preferences in more recent years. In Russia they reflect the ideas of so-called sovereign democracy, which is the ideological basis of both the domestic and international outlook introduced by Putin. ${ }^{14}$ In Uzbekistan they are tied to an even more fundamental question - that of the survival of the regime led by president Islam Karimov. ${ }^{15}$ As long as the Uzbek regime feels threatened by pressure from the West to expand democratic freedoms and improve its record on human rights, we should expect it to follow quite loyally the lead of its more powerful allies in the SCO.

\section{Perspectives}

The foreign policy record of the SCO is mixed. On the one hand, it is clear that overall the member and observer states have been voting in increasingly similar ways since 1992, when the post-Soviet member states were all admitted to the UN. This development may also be observed in Sessions 59-65, for which data for all ten states exist, although it is clearly slower and less unidirectional here. The data do not tell us whether the convergence has been caused mainly by socialization or by instrumentality, or when and how this has happened. More detailed studies of the individual states are required before we may say anything conclusively about this shift.

As voting patterns become increasingly similar, the risk for an individual state of committing itself to closer cooperation is reduced; it is simply less likely to find itself in a vulnerable outlier position or to be forced to compromise on important policy preferences. Continued convergence in this way suggests, all things being equal, that the SCO will find it still easier to widen and deepen its foreign policy cooperation and even to allow observer states to join the group of full members.

On the other hand, the slowing down of the process of convergence indicates that the member and observer states have reached a line that at least some of them will be reluctant to cross. What remains is likely to be a mixed pool of core preferences-for instance, on human rights, nuclear development, or weapons technology — which various constellations of states will continue to observe. The stability of the number of threeway splits in the 2000s points toward this same conclusion.

13 Aleksandr Chubaryan, "Osnovnye etapy vneshnei politiki Rossii," in Desyat let vneshnei politiki Rossii, ed. Anatoly Torkunov (Moscow: ROSSPEN, 2003), 26-32.

14 Various contributions in Leonid Polyakov, ed., Pro suverennuyu demokratiyu (Moscow: Evropa, 2007).

15 Matteo Fumagalli, "Alignments and Realignments in Central Asia: The Rationale and Implications of Uzbekistan's Rapprochement with Russia," International Political Science Review 28:3 (2007): 256-57. 
To this should be added the important fact that Russia remains a leading outlier. The policy convergence is a Chinese-led process, and it seems safe to assume that Beijing is more satisfied with this development than is Moscow. The lively public debate in Russia reveals growing concerns that the country is losing power relative to China - and that it is losing influence in post-Soviet Central Asia. ${ }^{16}$ The convergence discussed above, which sees the latter area tilting slowly towards China, may cause Russian policy makers to hesitate before committing to closer cooperation or to future SCO enlargement. What is good for China - and perhaps even for the rest of the SCO-is of course not necessarily good for Russia.

16 For a discussion, see Aleksandr Lukin, “Tsena vopros," Kommersant (17 June 2011); available at http://www.kommersant.ru/doc/1660857. 


\section{Bibliography}

Chubaryan, Aleksandr. "Osnovnye etapy vneshnei politiki Rossii." In Desyat let vneshnei politiki Rossii, 26-32. Moscow: ROSSPEN, 2003.

Deklaratsiya o sozdanii shankhaiskoi organizatsii sotrudnichestvo. Shanghai Coooperation Organization, 2001.

Fumagalli, Matteo. "Alignments and Realignments in Central Asia: The Rationale and Implications of Uzbekistan's Rapprochement with Russia." International Political Science Review 28, no. 3 (2007): 256-57.

Hansen, Flemming Splidsboel. "The Shanghai Cooperation Organisation." Asian Affairs 39, no. 2 (2008): 217-32.

Holloway, Steven. "Forty Years of United Nations General Assembly Voting." Canadian Journal of Political Science 23, no. 2 (1990): 279-96.

Johansson-Nogués, Elisabeth. The Voting Practice of the Fifteen in the UN General Assembly: Convergence and Divergence In Working Paper. Observatori de Politica Exterior Europea, 2004.

Johnston, Alastair Iain. "Is China a Status Quo Power? ." International Security 27, no. 4 (2003): 5-56.

Luif, Paul. EU Cohesion in the UN General Assembly. Occasional Papers . Institute for Strategic Studies, 2003.

Lukin, Aleksandr. "Tsena voprosa." Kommersant (2011).

Polyakov, Leonid. "Various contributions." In Pro suverennuyu demokratiyu. Moscow: Evropa, 2007.

Voeten, Erik. "Clashes in the Assembly." International Organization 54, no. 2 (2000): $185-215$. 